\title{
FORGOTTEN STORIES OF WOMEN: INTERGENERATIONAL TRANSMISSION OF TRAUMA OF HOLODOMOR AND HOLOCAUST SURVIVORS' OFFSPRING
}

\author{
Larysa Zasiekina \\ https://orcid.org/0000-0001-8456-0774 \\ Scopus ID: 57215414977 \\ zasyekina.larisa@vnu.edu.ua
}

Lesya Ukrainka Volyn National University, Ukraine

Becky Leshem https://orcid.org/0000-0002-7542-7442

Scopus Author ID: $\underline{36774949200}$

beckyleshem@gmail.com

Achva Academic College, Israel

Tetiana Hordovska

https://orcid.org/0000-0002-0445-9615

hordovska.tetiana@vnu.edu.ua

Lesya Ukrainka Volyn National University, Ukraine

Neta Leshem

netaleshem@campus.technion.ac.il

The Hebrew University of Jerusalem, Israel

Ruth Pat-Horenczyk

https://orcid.org/0000-0002-5589-8837

Scopus Author ID: $\underline{15832850900}$

ruth.pat-horenczyk@mail.huji.ac.il

The Hebrew University of Jerusalem, Israel

Received February 2, 2021; Revised March 28, 2021; Accepted June 1, 2021

\begin{abstract}
The aims of this study were to examine the intergenerational effects of two cultural contexts of massive genocide, the Holodomor 1932-1933 in Ukraine, and the Holocaust 1939-1944, on the second and third generations of women in Ukraine and Israel. Forty women participants were recruited for four focus groups, two in each country, comprised of 10 participants each, using a snowball method in both countries. The second-generation groups were termed 'the mothers' group", and the third generation group (comprised of daughters of the mothers' groups) were called "the daughters' group". Inclusion criteria for sampling were (a) being female over 18 years old, and (b) having a family experience of the Famine 1932-1933 / Holocaust, 1939-1944. The groups were
\end{abstract}

(C) Zasiekina, Larysa; Leshem, Becky; Hordovska, Tetiana; Leshem, Neta; Pat-Horenczyk, Ruth, 2021. This is an Open Access article distributed under the terms and conditions of the Creative Commons Attribution 4.0 International Licence (http://creativecommons.org/licenses/by/4.0).

East European Journal of Psycholinguistics, 8(1), 137-158. https://doi.org/10.29038/eejpl.2021.8.1.zas 
moderated by two experienced psychologists in each of the countries. The participants were presented with seven semi-structured questions and were asked to share their family narratives and experiences of the genocide. The study applied inductive thematic analyses that progressed from description to interpretation, for key themes that emerged during the group sessions. The results of the study showed the centrality of five emerging themes in both mothers' and daughters' narratives, including "emotions and feelings of experiencing genocide, "attitudes toward food and starvation", "sense of loss and death", "transgenerational transmission of trauma in family narratives", and "ethnic identity". The cross-cultural perspective of the current research shed light on the similarities and differences between the traumatic narratives constructed by the offspring of the second and the third generations in the two contexts of Ukraine and Israel. The Ukrainian women attributed greater importance of commemoration of Holodomor victims as part of an effective coping strategy with trauma, while the Israeli women put more emphasis on the adoption of asceticism that was inherited from the Holocaust survivors. The cross-cultural clinical and educational implications are discussed.

Keywords: female offspring of Holodomor/Holocaust survivors, mothers-daughters' narratives, psychotrauma of genocide, transgenerational transmission of trauma.

Засєкіна Лариса, Лешем Бекі, Гордовська Тетяна, Лешем Нета, Пат-Горенчик Рут. Забуті жіночі історії: трансгенераційна передача травми серед нащадків жертв Голодомору та Голокосту.

Анотація. Мета статті - вивчення трансгенераційного впливу двох геноцидів: Голодомору 1932-1933 та Голокосту 1939-1944 на друге і третє покоління жінок нащадків цих геноцидів в Україні та Ізраїлі. Вибірку склали 40 осіб жінок, які брали участь у чотирьох фокус-групах, по дві фокус-групи (фокус-група матерів (друге покоління) та фокус-група дочок (третє покоління) у кожній країні, з кількістю 10 осіб у кожній групі. Основними критеріями для включення у фокус групу слугували а) приналежність до жіночої статі та вік понад 18 років; б) досвід Голодомору 1932-1933 / Голокосту 19391944 у родині. Модераторами групи були два досвідчених психолога у кожній країні. У дослідженні використовувався метод напівструктурованого інтерв'ю, упродовж якого досліджувані розповідали про досвід родини стосовно геноциду. Напівструктуроване інтерв’ю містило сім запитань: який досвід мала родина під час геноциду; як геноцид вплинув на їхню особистість; як вплинув геноцид на їхнє уявлення про себе, їхнє фізичне та психічне здоров'я; як вплинув геноцид на їхні стосунки зі значущими для них людьми; як вплинув геноцид на їхню професійну діяльність та їхнє професійне зростання; про які події, пов'язані із геноцидом, вони розмовляють зі своїми нащадками; що для них $\epsilon$ найважливішим у їхніх спогадах. Результати використання методу індуктивного тематичного аналізу у сукупності описового та інтерпретаційного етапів свідчать про наявність п'яти спільних тем у фокус-групах дочок та матерів у двох різних культурних контекстах. До цих тем належать емоції та почуття стосовно Голодомору/Голокосту, ставлення до їжі та голод, сенс втрат та смерть, передача травми у сімейних наративах, етнічна ідентичність. Результати дослідження також дали змогу встановити відмінності у наративах жінок другого і третього покоління стосовно геноцидів у двох різних культурних контекстах. Українські жінки великого значення надають вшануванню пам'яті жертвам Голодомору як способу упередження геноциду у майбутньому. Жінки Ізраїлю акцентують увагу на аскетизмі та скромності, які успадковані від жертв Голокосту. Висвітлено кроскультурні клінічні та освітні аспекти проведеного дослідження.

Ключові слова: нащадки жертв Голодомору/Голокосту жіночої статі, наративи матерів та дочок, психічна травма геночиду, трансгенерачійна передача травми. 


\section{Introduction}

The twentieth century witnessed massive genocide that claimed the lives of 262 million victims, among them Jews and Ukrainians who suffered during both the Holocaust and Holodomor (Bemporad \& Warren, 2018). A key aspect of genocide is that its effects last far longer than the physical annihilation of people, which may lead to transgenerational transmission of negative consequences. Evidence has suggested that psychotrauma in the context of genocide has been associated with various disorders in intergenerational communication within the survivors' families and with further disturbances of identity and wellbeing among the second generation (Brom, Kfir, \& Dasberg, 2001). Studies focusing on different genocides have also shown the importance of transgenerational transmission of the narrative of collective trauma. Data from several studies suggest that there is increased anger, PTSD and experiences of continuous traumatic stress (CTS) in Holocaust survivors' offspring (Bar-On et al., 1998; Braga et al., 2012). Ethnic-related shame and guilt are defined as markers of moral injury in families affected by the Armenian genocide (Karenian et al., 2011). Increased suicides, helplessness and hopelessness are frequently encountered in the offspring of Canadian aborigines (Elias et al., 2012). Evidence consistently suggests that Chinese survivors avoid sharing family narratives about the Famine 1959-1961 in China with their offspring (Bianco, 2013; Weigelin-Schwiedrzik, 2006).

Less is known, however, on the impact of mass violence and political oppression specifically on women, and in particular, on mother-daughter relationships. Notably, Neimark (2001) argued that genocide is always misogynistic and directed predominantly at women, since they are "the cultural and biological repository of nation" (p. 83). Further, Bemporad \& Warren (2018), capturing the key psychological effects of different genocides on women, and in particular, the lives of German-Jewish women in the Nazi-occupied East during the Holocaust and cases of cannibalism in the Holodomor, point out that traumatic memory is predominantly gendered; therefore, women's memory of genocide involves a deeper insight into political violence and oppression.

A women-centered perspective in genocide research was suggested by Jacobs (2004) to consider "gender-specific" traumas such as sexual assault, reproductive abuse, killing or abandoning children (p. 230). Regarding these "gender-specific" traumas, genocide represents experience, emotions and feelings for women, which may differ from those reported by men. Considering the fact that women often serve as the main translators of family narratives, the exploration of female transgenerational transmission of the personal and community narrative of genocide is of crucial importance. In addition, reconstruction of traumatic memory by women is a robust predictor of reconstituting post-trauma identity at both personal and collective levels (Rajiva \& Takševa, 2020).

Exploring family narratives in females of the second and third generations could highlight the transgenerational mechanisms of transmission of psychotrauma in the context of genocide. It can shed light on the consequences of this 
intergenerational transmission on both the distress level and the wellbeing of the subsequent generation, and clarify possible risks and protective factors (Bifulco, Spence, \& Kagan, 2020). Individuals in the midlife phase often search for family history in order to pass it on to the younger generations (Freedman, 1999; Hammarström, 2005).

Yet, given the survivors tendency to avoid communicating about their traumatic experience (Fierke, 2004; Richman, 2006; van der Kolk, 2015), the third generation may have only a limited or basic idea of what happened to their parents during this traumatic period of time. Even when assuming relatively close relationships between mothers and daughters, sharing narratives among the generations may be complicated and may contribute to understanding the obstacles and the challenges in transgenerational transmission of psycho-trauma.

The aim of the proposed study is to extend the understanding of intergenerational transmission of genocide trauma, and specifically, to examine intergenerational effects of two cultural contexts of massive genocide; the Holodomor 1932-1933 in Ukraine, and the Holocaust Europe, 1939-1944, on the second and third generations of women in Ukraine and Israel.

\section{Women's psychotrauma of the Holodomor}

Bertselen (2018) argues that women have been target victims in any ethnic and political cleansing during genocide. With starvation as the main tool of genocide, the Holodomor is expressed not only in mental trauma but also with "moral injury" among women. Women had to break moral norms and rules in order to themselves survive and to save their families, sometimes committing crimes in a continuing search for food. Bertselen (2018) points to the existence of cannibalism, which led to defense mechanisms in order to cope with dehumanization, depersonalization, and lost-self-identification in women during the Holodomor 1932-1933. Having developed a new identity during the Holodomor, women rejected and resisted it at the same time because of its mismatch with their previous values and moral standards. However, this ambivalent identity allowed women partially to compensate distortions of moral norms, values and judgements, adjust to new patterns of immoral behaviour, and diminish moral emotions of disgust and anger. Kis (2020) points out that women's stories encompass about three quarters of all formal testimonies of the Holodomor, in which the idea of a mother's unconditional love and acceptance is partially destructed. Having described the concept of "besieged mother" as a set of mothers' behavioral patterns and practices aimed to save their starving children, the Ukrainian scholar defines the main adaptive strategies in mothers, in particular, committing themselves to children's survival, demonstrating self-sacrificing behaviour or rejecting their maternal duties and saving their own lives at any cost. Self-sacrificing behaviour was manifested in their open protests against the government, in protecting their subsistence and searching for food, and even by means of survival prostitution. However, there were cases 
when mothers abandoned their children, making attempts to save adult family members or themselves in life-threatening situations.

\section{Women's mental trauma of the Holocaust}

Most often, the coping strategies of women in the ghetto have been described in a non- judgmental way acknowledging the survival needs in adapting to the abnormal circumstances and the harsh reality of the Holocaust (Chalmers, 2015).

One of the most pressing needs of mothers during the Holocaust was to provide food for their children and family. In this regard, it was necessary to be creative, and sometimes to break moral rules. There is evidence of how mothers spared their own food and passed it on to their children and how other women worked harder in order to obtain more food vouchers (Sinnreich, 2017; Waxman, 2017). Even in these extremely difficult circumstances, the traditional Jewish symbol of success, or what is termed "Eshet Chayil" (a woman of valour) was maintained and measured in food provision.

The literature on the Holocaust tends to disregards immoral behavior among women as a method of coping for survival (Person, 2015).

Men were commonly deported to labor camps and some died; thus, women had to cope with the responsibilities for their children alone. Some sought the protection of men for existential needs and paid the toll. There were cases of forcing women into relationships with men, leading to shame and guilt about using of sexuality for survival, although these narratives were silenced for many years (Person, 2015).

Together, these studies provide important insights into maternity as a core value in women during genocide and appeared as the most widespread topic in the Holodomor and Holocaust female testimonies. However, existing studies are based on personal narratives of women, and do not consider family narratives in motherdaughter relationships as a marker of transgenerational transmission of genocide trauma.

Therefore, the specific objective of the study is to explore women's understandings, opinions and views of the Holodomor and the Holocaust, and elicit transgenerational mechanisms of genocide trauma in mother-daughter interviews.

\section{Methods}

\section{Ukraine}

Snowball sampling was used to recruit two female nonclinical sampling groups, that is, a sample of the second generation, termed "the mothers group", and the third generation, referred to as the "the daughters group". Samples were selected through the Holodomor Research Institute in Ukraine in order to conduct focus groups. Each mother and daughter represented one family who had experienced the Holodomor. Inclusion criteria for sampling were: (a) being female and above 18 
years old, and (b) having a family experience of the Famine 1932-1933. A total of 20 women (mothers and daughters) participated, 10 women in each focus group. Mothers ranged in age from 65 to $77(\mathrm{M}=79.00$ years, $\mathrm{SD}=16.97)$ and daughters ranged from 37 to $49(\mathrm{M}=44.17$ years, $\mathrm{SD}=12.58)$. Participants are from Khersonska, Poltavska, Luhanska, Donetska, Vinnytska, and Kyivska Oblasts.

\section{Israel}

The Israeli participants were recruited using a similar method of snowball sampling. Two groups of participants were created: "the mothers group" and "the daughters group". All mothers were the second-generation of the Holocaust (daughters of Holocaust survivors, either father or mother) and the group of daughters consisted of matched third-generation young women (each mother paired with one of her daughters or vice versa). Sampling inclusion criteria were similar: (a) women over the age of 18 , and (b) Holocaust family history experience during 1939-1944. The full sample included 20 women -10 mothers of the second generation, who participated in a focus group (age range $=50-70, \mathrm{M}=59.5, \mathrm{SD}=$ 6.8) and the matched group of 10 daughters, the third generation, who participated in a separate and parallel focus group, age range $=22-38, \mathrm{M}=25.1, \mathrm{SD}=6.1$.

\section{Procedure}

Two separate focus groups for mothers and daughters were conducted in each of the countries and contexts. At the beginning, the focus-group moderator outlined the objectives of the study, how data might be used and withdrawn, and because of traumatic memories, details of counselling services were provided. According to focus group method and the methodology suggested by Parker \& Tritter (2006), the objectives of the project, the procedure of data transcription, analysis and dissemination were discussed. Moreover, confidentiality and anonymity were underlined, and participants were provided with an opportunity to select their own pseudonyms for the final research report.

The focus-group moderators, in both contexts, presented seven questions, requesting the participants to share their personal experiences vis-à-vis genocide in their families, and to elaborate on their emotional and cognitive responses in the group discussion. The group discussion included the following guiding questions: (1) What experiences have you had linked to the period of genocide (the Holodomor/ Holocaust)? (2) How does the Holodomor/Holocaust affect you personally in general? (3) Given that the Holodomor/Holocaust experience is greatly traumatic, what is the Holodomor/Holocaust impact on your sense of self and your physical and mental health and well-being? (4) How does the Holodomor/Holocaust affect your family, and relations with your family members and significant others?

(5) How does the Holodomor/Holocaust affect your work and professional growth?

(6) What events, people or themes associated with the Holodomor/Holocaust have 
you discussed with your descendants? (7) Of everything we have talked about, what is most important to you?

\section{Method of analysis}

The study applied inductive thematic analyses that progressed from description to interpretation for each of the key themes, ranging from essentialist to constructionist paradigms (Braun \& Clarke, 2006). The inductive thematic analyses were conducted in several stages. First the researchers from both countries agreed on a list of a priori codes that classified sentences/groups of sentences. Then, an independent research assistant in each of the context used this list of codes in each of the data sets.

\section{Results}

Our findings revealed six key themes in the Ukrainian sample: (1) Attitudes toward food and starvation; (2) Emotions and feelings, experienced during the Holodomor; (3) Sense of loss and death; (4) Transgenerational transmission of trauma in family narratives; (5) Coping strategies with trauma; (6) Ethnic identity. In Israeli samples six themes were revealed, in particular (1) Excessive worry about hunger and starvation (2) Transmission of emotions and feelings, (3) Childhood loss and loneliness, (4) Family values and family cohesion, (5) Increased Zionist identity, (6) Asceticism and ascetic lifestyle.

\section{Common themes in the Ukrainian and Israeli samples}

\section{Emotions and feelings experienced during the Holodomor/Holocaust}

Mothers' and daughters' concerns about their family's emotions and feelings were highlighted when they talked about how tragic the experience of the genocide was for their entire nation and for their family. A primary relevant concern was how emotions had been intensifying with the age of participants and their level of awareness of genocide. They described different types of emotions and their intensity, ranging from no emotion to terror.

A participant in the daughter sample shares how her experience was especially difficult, which resulted in feelings of outrage regarding the Holodomor.

I accepted all these memories easily when I was a small girl and did not realize how it was possible to live without food. However, growing up, my easiness transformed into great anger towards the Soviet government, which made my family suffer and die. If I took a machine gun, I would kill the entire government which was responsible for Holodomor victims. 
A common view among interviewees was that they remember how Holodomor survivors felt fear when they talked about it, related to the possibility of starving and dying again. This fear took a different form among mothers and daughters as direct descendants of Holodomor survivors, namely, the fear of uncertainty and lack of security in Ukraine. One concern relating to fear in daughters' interviews was their attempt to share this information with their children in a way which would diminish fearful feelings about this tragic experience.

I spoke with my children about starvation during the Holodomor and focused on how careful we should use bread and how valuable bread is, instead of talking about tragic facts and deaths from starvation. I remember when my grandmother spoke about the Holodomor, our mother kissed and hugged me and my brother as if she wanted to protect us from all that.

Many participants in the Ukrainian samples noted that there was a lot of suffering and pain in their families.

My mother often told us how much they suffered from starvation and she expected deep compassion from me and my children. It is very painful when significant others are suffering from their memories, experiencing them in vivo again and again, and your only wish is to assuage their suffering. It was complicated to support my grandmother when she was speaking about the Holodomor, since there is great pain, not in her body, but in her soul.

In summary, these results show that fear, anger, and outrage are the key emotions in mothers' and daughters' memories about their family's experience of the Holodomor. There is trepidation about recurrent starvation, fear that significant others could leave and not come back, chronic anxiety that something terrible might happen. The long-term fear of recurrence of genocide is also observed in the Israeli samples of mothers and daughters. Sometimes the only way to cope with anxiety and fear has been linked to mothers' overprotective behaviour.

I was waiting for that day. I knew that one day the Holocaust was coming, so I got organized. There's nothing to worry about; I'm fine now. I mean, the Holocaust is here all the time - I'm waiting, getting ready. I'm not alive. Sometimes I feel like my mom is very anxious. Even when there is no reason. And it's like, yeah, I connect it as a way of coping. I think I'm a more frightened person. I run, jump every time I hear the door. I have obsession with the children. I wrap them up too much, I'm aware of that.

The experiences of the Holodomor and Holocaust have implications of moral injury, defined as psychological distress felt when individuals perpetrate, witness or fail to prevent actions which violate their core moral assumptions and beliefs (Litz et al., 2009). Considering the idea that the Holodomor violated core moral assumptions and beliefs (Zasiekina \& Zasiekin, 2020), we assumed that there were moral emotions in transgenerational mechanisms of this historic trauma. Results show that Ukrainian daughters reported behavioural deviations of moral standards in their mothers. However, there were no emotions of guilt or shame, even when 
immoral patterns of behaviour occurred in their families. Instead, emotions of anger and outrage towards the Soviet government were expressed.

My mother went with her parents to a rich family to sell clothes, and while there, stole bread and brought it home.

My grandfather went to the field to search for any food and was accused and arrested for stealing wheat.

The Soviet government organized this genocide. They wanted to annihilate the Ukrainian people, many people died, I hate the Soviet regime with all my heart. The Soviet time was a time of serfdom.

Quite different emotions are observed in offspring of Holocaust survivors, ranging from fear to emotional numbness. Sometimes emotional inability was related to mistrusting others. The Israeli mothers described the intergenerational transmission of the Holocaust as manifested in feelings and emotions that emanated from their parents and were an integral part of their upbringing. They described the messages they had received as: "Do not fall in love", "Do not connect", and they felt that they might have transmitted these life messages to their daughters. One of the mothers described her father's attitude towards dogs that showed his traumatic memories. The Israeli daughters also talked about the long-lasting Holocaust lessons, expressed by their mothers, and they outlined emotional consequences of the Holocaust in mother-daughter relations.

I think we could not love. It was too much for us. I have such a feeling of missing out. There is also the relationship with my brother. Also my interpersonal relationships with others. I mean, I'm just a sociable person, but not too much. I mean, I'm protecting myself.

Mom told me 'Do not believe anyone, Do not explain to anyone, Do not love and do not hate... I mean that 'Do not touch', 'Do not love too much', 'Do not believe in anyone', but also 'Do not be angry with anyone'; that means, 'Keep things to yourself'.

It means that you don't break down, even if it's hard, don't break down. It means 'Right, it's hard; get over it'. 'It will not help now if you cry, or something like that'. And so, as a child, when I fell and got hit, I was forbidden to cry. It was regarded as shameful - You could cry watching a sad movie, but not in response to physical pain.

He resisted very strongly to our adopting a dog, because a dog is something that you get attached to, and he really opposed it.

She is a wonderful mother, but she has never complimented or encouraged. I felt I might be disappointing my mother. She has no patience in any situation.

\section{Attitudes toward food and starvation}

Many emotional consequences of the Holodomor and Holocaust are linked to the themes of starvation, body sensations, and attitudes to food. The theme of 
starvation and its negative effect on body sensations recurred throughout mothers' and daughters' dataset in the Ukrainian and Israeli samples. This theme came up for discussion, for example, in their family experiences during the Holodomor and responses to lack of food, when the body would begin to swell: "She was thirteen and very weak; her body was swollen. Father said if she lives for at least a day, she could survive and live", "His legs swelled up and his mother used the last chestnuts to make flour."

All participants talked about the impact of the Holodomor on current family traditions related to food. There are four important concerns about food. One was a current family tradition to have much food for holidays and food as a symbol of family hospitality and well-being: "When we celebrate some holiday, my mother and my husband always overeat, ant they say that holidays should be accompanied by much food".

The second concern, relating to daughters' memories, includes episodes when their grandmothers and mothers gave them extra food to be sure that they were completely full. These episodes resulted in being overweight and daughters' attempts to stick to a diet.

I remember that my grandmother and mother overfed themselves and overfed me, and I suffered from being overweight and stuck to a diet to avoid these problems. In addition, my mother always ate too much and had diabetes type II, and I was afraid that I might have it too.

I remember that I was angry with my grandmother for eating high fat cream and a lot of butter, but when I made any remarks, my grandmother just smiled and commented that it was delicious.

My mother told us that it was unacceptable to stick to a diet when there was a lot of food everywhere.

The third concern, expressed in mothers' and daughters' memories, related to a deep respect for bread: "I always heard that I should take a large amount of bread when I could get it", "I remember that my grandmother put a piece of bread under her pillow, when she was going to bed", "I see how my grandmother picks up all of the crumbs of bread from the table with her slim dry hands", "My grandmother said that we shouldn't throw away any piece of bread, instead, to eat, to share with somebody, or to feed pets or birds, but not to waste".

Finally, many mothers' and daughters' concerns pointed to the necessity to be thrifty and to have reserves at home, and in particular, porridge, beans, and flour, in order to feel safe and confident in the future.

The preoccupation with food is also observed in mothers' and daughters' focus-groups of the Israeli samples. They mention that "[w]e always had to finish the food on our plate. Especially with Grandma at home, there was no such thing as a plate remaining full. And in our home, Mom always checked that there was room left in her stomach for what was on the plate". However, the relationship with food 
was explained rather by family traditions than by starvation per se: "We had a closet full of preserves and flour and sugar. And we had to eat at home to the last bite. To finish everything on the plate... I passed that on to my kids too".

The Israeli mothers described their parents' hunger-related traumas as a significant part of their lives. They expressed hoarding, preparing for "hard days"; they described the difficulties of throwing away food, not finishing all the food on one's plate and hoarding food for the difficult days to come: "The full food storage cabinets, having to finish eating all the food on your plate... I passed that on to my children. That's how I am; I always have stacked food closets"; "Throwing away food was forbidden. It wasn't allowed to throw rotten fruit, stale bread... nothing was thrown away".

One mother in the Israeli sample noted that there were some rigid rituals related to food while eating.

There was a ritual that repeated itself at every Saturday meal - there was a kind of rotation, because... kids don't finish their food. Then the plates were given to my father and he would finish the food. And he would only stop when I brought a dog and he knew that the food would be given to the dog and not thrown away. If my brother couldn't eat the peel of a peach my father would get very angry with him and force him to eat the peel.

Hunger has taken on a great significance in Holocaust survivors' lives. It has been a lifelong theme that has been hard to ignore and it has even triggered cases of rebellion.

When my mother was making a scrambled egg she would scramble it in a cup and then pour it into the pan and keep scraping the cup for half an hour as if something had been left in the cup so nothing was wasted. When I scramble an egg, I pour half into the pan and throw away the other half and it's obvious that I'm doing that out of spite.

The Israeli daughters described their experiences with their grandmothers and mothers and emphasized that the hunger-related characteristics were also passed on to them.

It's like... to make sure there is always enough food and to prepare 18 dishes even if there are only five people at the table. Like... to be angry when you haven't finished all the food on your plate, even if, just seconds ago you ate at a friend's home or something like that. These are the more standard habits that I think our mother inherited from our grandmother and... and I myself have an issue with food (hunger), I cannot bear to hear anyone tell me that he is hungry.

The thing with food, preparing it and such. Now that I have lived with roommates, it was really like... my job, like cooking, setting the table and making sure that there would always be enough food for everyone, like for all my friends... that the foods that they like would always be in the fridge. I'm not sure if or how this was passed on to me but I feel like it's a habit that I got from my mother. 
It's like that, yeah... it's like... it's pretty personal, but it's also...Hunger is one of the most salient features of the traumatic consequences.

\section{Sense of loss and death}

The themes of loss and death recurred throughout the dataset, in mothers' and daughters' interviews in the Ukrainian and Israeli samples. The interviewees reported loss of such a great number of people who died of starvation during the Holodomor. A repeated theme centered around the inability to bury the dead. As a result, dead bodies were everywhere, strengthening the terror of those who were left alive: "My husband's mother survived physically during the Holodomor, but she is still injured mentally, so my husband also felt mentally distressed", "In our village there are individual graves for Holodomor victims with wooden crosses in every home yard or between them, because people were too weak to bury them in village cemetery". In some villages there was a special burial for Holodomor victims: "In 1990 we discovered the place in our village where many Holodomor victims were buried, so we collected money and put a memorial on the grave, but in other places - there was no special burial, and individual graves are in different places in the cemeteries"; "There is no special common grave in our village, but we know where they were buried in the village cemetery, and when we visited our relatives' graves we brought bread for burial of Holodomor victims".

Concerns were also expressed about family members who went to the cities to work in factories and plants in order to earn money and provide food for their families, but never came back. They died of starvation or were arrested on their way and then later, died.

In the Israeli sample, loss centered around the loss of childhood. The loss of childhood is also associated with complicated and serious life problems, problems which could not be solved during the genocide period.

What I took with me is this responsibility to the end and maybe with too much seriousness, I mean now I'm dealing with a place in my life and trying to be a child again and asking myself what I really like to do, because I think I had some kind of fast growing up and I did not allow myself to be a child.

The Israeli mothers reported that they hadn't experienced a normal childhood, as their parents were anxious about their daughters' lives while being occupied by their own traumas. All mothers described abnormal childhoods with an environment of deprivation, unmet needs and restrictions: "They guided my life"; "I can't recall a single time that I came to consult with them; they were never the person you would turn to for consulting on anything"; "They had stopped us...I was very much stopped".

The loss of childhood had a poor impact on attachment and close relations between mothers and daughters. 
I haven't brought anything up with them. Until today they don't know things about me... nothing bad or... painful... I was diagnosed with cancer five years ago and I hid it from my parents. They don't know I had cancer. I've been through cancer without their knowing. So they don't... It's just impossible to show... that something is wrong... that something could be threatening.

I moved out at a young age, like twenty-one or twenty-two... I chose to learn in Tel Aviv which is where I matured. It was where I learned to live, to stand alone on my feet, because... when I lived in... at home, mom was really... she was a real character... she was really caring but also judgmental, regarding everything, and... I had to spread my wings in order to grow up.

Among the Israeli daughters, the loss of childhood felt "gradual", affecting the older children more than the younger ones: "The oldest daughter, I think, has far greater (childhood) consequences than the third daughter. I think that with her they were a little more...".

Findings suggest that adult daughters put a lot of effort into balancing their parenting styles with their firstborn child, "easing off" on their younger children, unlike their mothers, who maintained their parenting style and passed on Holocaust experiences equally to all the children.

\section{Transgenerational transmission of trauma in family narratives}

Most participants emphasized the importance of transgenerational transmission of traumatic events in their family narratives. There are two opposite strategies of Holodomor trauma transmission. The first is to talk about Holodomor experiences and share the whole truth with the offspring of Holodomor witnesses. The second strategy is to avoid any conversations referring to the Holodomor as an attempt to cleanse their memory and protect their descendants: "Nobody knew that this place was a grave until an old woman pointed to it. She kept the secret because it was unsafe to talk about it earlier", "I did not know that my grandfather had died of starvation. Nobody told me about it, I just thought that I had never had a grandfather", "My grandmother never spoke to me about the Holodomor; The only person who talked to me about it was my mother".

Considering the increasing number of words, higher coherence, and the more detailing of episodes in the daughters' interviews, we assumed that each following generation would be able to speak more freely about these events. This finding is in line with other research, indicating that, rather than ruminating on the pain, the third generation focus attention on their ancestors' courage, resulting in the offspring's ability to avoid the pathological symptoms (Kahane-Nissenbaum, 2011).

One possible explanation is that the later the generation, the less traumatic it feels. This is in line with our finding of mothers' parenting styles being more severe with their first born child and "easing off" on their younger children. One interviewee argued that she could not understand why her mother had not disclosed the story about hiding food in their yard during the Holodomor, because this was 
one of the key episodes in family Holodomor history. Evidence constantly suggests that even if there were no shared memories in the family, there were other ways of trauma transmission through the generations: "I remember my grandmother always keeping silent and weeping as if she concealed something from us".

Offspring of Holocaust survivors emphasized the family values in their family narratives. The readiness to talk about tragic events with offspring is expressed in interviews.

We have a very large family, full of children and ... she always talks about the suffering that took place in the Holocaust, about how good it is now - about having such a big family, and what happiness it is to see so many kids and that... there is always joy and fun in the family now ...

The Israeli mothers talked about their parents' traumatic experiences and their own, mixing them during the discussion, as if they themselves had experienced the Holocaust. "These are my dreams, there are Nazi figures in my dreams, and this tells me that something in my life right now is disorganized, I'm under some sort of stress..."; "I hear myself talking incoherently now... all sorts of things are jumping out of me (into the discussion), just like the story of the Holocaust in my life"; "The Holocaust is burned into my soul".

The Israeli daughters focus on their mothers' feelings rather than on their own, describing their mothers' traumatic experience. In addition, they noted that there is transgenerational transmission of post-traumatic stress and anxiety in their families: "I feel like I'm a daughter of a mother who is the daughter of a Holocaust survivor. It's not that she has any oddities, but simply - it's something that is present in my mother's life"; "The concern is something internal that doesn't come out as if it stays inside. It doesn't come out"; I think that "I have learned from my mother a feeling of anxiety...".

Together, these results provide important insights into in the mechanisms of trans-generational transmission of trauma, which are accompanied by non-verbal behaviours, expressing negative emotions of anxiety, fear and sadness. Therefore, narratives as a main tool of trauma transmission also involve non-verbal behaviour to express internal suffering and pain aligned with the genocide.

\section{Ethnic identity}

Comparing the two samples, it can be seen that ethnic identity is strengthened in both cultural contexts. The theme of ethnic identity highlighted the pressure of the Soviet government on Ukrainians and their strong national identity: "The Soviet government hated everything significant for Ukrainians and was directed towards the destruction of Ukrainian nationalism. Talking about the Holodomor now is 
emphasizing that I am Ukrainian, and I will protect everything which is significant for Ukrainians", "Disclosing the truth of the Holodomor means a change of my worldview, the awareness that I was fed up with the lie about our history, and I need to know facts about the new history of Ukraine without Soviet propaganda", "Ukrainians had everything, and they transformed Ukraine into nothing; now it is high time to restore the truth and Ukrainian identity and strength".

The Israeli interviews highlighted ethnic identity in the form of Zionism, expressing the crucial importance of Israeli land, state and community for the Jewish people: "That the Land of Israel, or the State of Israel or whatever it's called, is a very important anchor for us as Jewish people"; It's very much like immigration to the country and the establishment of the state ... and they very much emphasize it, precisely in the stories, this part of ... a Jewish state, it's something they are very, very proud of it and they base their lives on it".

For the Israeli Holocaust survivors and offspring, the Holocaust affects their national identity, clearly reinforcing their Zionism, as both mothers and daughters emphasized the importance of the establishment of the Jewish state and the feeling of duty to the state. For them, Israel is the only place for Jews and there is no other option.

My father played an important part in all the wars (in Israel). Every time we toured Israel, he would say 'I fought here' and 'I conquered here' and 'I did this here'. Later, seeing every child inducted into the army and seeing us all in (IDF) uniforms... I think that it was the most important thing for him. Everyone had to enlist (into the Israeli army) and everyone had to contribute to safeguarding the country, because that is the most important thing - we have to preserve what we have (the Jewish state).

The Land of Israel, or the State of Israel, or whatever we call it, is a very important anchor for us as the Jewish people. This is something I grew up on. I applied and received Hungarian passports for myself and my children and I kept saying that my dad probably flipped over 10 times in his grave, when he heard that I have a Hungarian passport.

\section{Different themes in the Ukrainian and Israeli interviews}

\section{Coping strategies with trauma in the Ukrainian interviews}

This theme depicts a list of behavioural patterns and strategies to cope with trauma. The mothers pointed out how their family members had struggled for survival, particularly eating different plants, chestnuts, and corn to cope with the starvation; they went to the towns and cities if possible to search for jobs and to earn a living; starving themselves and giving everything they could get for children, in order to save them from death. The coping strategies of mothers' and daughters' include commemoration of Holodomor victims with candles in November, visiting burial sites of Holodomor victims and talking with their descendants about it. Most Ukrainians noted that it is important to commemorate the Holodomor at society and state levels, since it develops the strength of community and its future: "It is of 
crucial importance to teach Holodomor history at schools, to share the truth about Holodomor events in the world, on one hand, to relieve the pain of Ukrainians, and on the other hand, to prevent such genocide in the future", "We have shared the truth of the Holodomor with the world, since it was hidden from people by the Soviet government".

\section{Asceticism and an ascetic lifestyle in the Israeli interviews}

The Israeli mothers inherited modesty and abstinence, characteristics of their Holocaust survivor parents. For the mothers, a roof over your head and enough food at your home are enough, and everything else is a bonus that one doesn't have to use. "I think it related to my education that I... I am very modest. I am not a miser, I travel abroad and everything but I really enjoy the small things just like my mom"; "I'm happy with what I have today. With the house, with the children, with my husband, with the surroundings. I'm happy with what I have, and I protect what I have".

The mothers lived ascetically, as their parents did, but these perceptions of asceticism had not been rooted in the insights they passed on to their daughters. In contrast, they even conveyed the "better live well" message. "You should always appreciate what you have, live well, live the present, all is well, be optimistic"; "Even in shopping for things, I buy what I see without overthinking. If I see a garment, I measure it, I try it on, unlike my mother. It takes her hours to decide to buy something".

\section{Discussion}

As mentioned in the literature review, prior studies have noted the importance of women's experience of genocide in the context of transgenerational transmission of psychotrauma through family narratives. The present study was designed to determine the effects of the Holodomor 1932-1933 in Ukraine and the Holocaust 1939-1944 in the second generation (midlife: born 1940-60) and third generation (born 1970-1985) women. The most interesting finding was that there are similar themes appearing in womens' narratives vis-à-vis their indirect experience of genocide, namely, emotions and feelings, experienced during the Holodomor/Holocaust, attitudes towards food, loss and death, transgenerational transmission of trauma in family narratives, and ethnic identity. Our data reveal the great pain and suffering in female family narratives, mostly expressed in the longterm emotions of fear, anxiety and anger. One unanticipated finding was that the Israeli mothers taught their daughters to avoid emotions and feelings as a coping strategy to prevent pain and suffering. This data is consistent with previous research on the activation of defense mechanisms, namely, emotional frozenness and avoidance in Holocaust survivors (Barak \& Szor, 2000). However, we know little about transgenerational mechanisms of avoiding emotions in mother-daughter 
relations. Therefore, our data raise questions for clinical psychologists about emotional inability and emotional numbness in female offspring of genocide victims.

Challenging the idea that emotions of shame and guilt could appear when individual behaviour deviates from moral standards (cases of thieving, cannibalism, prostitution) in order to survive, the study examined moral injury experienced by female offspring of Holodomor victims. Our findings suggest that, instead of shame and guilt, which are associated with moral injury, Holodomor offspring experience anger, and outrage towards perpetrators. Therefore, the circumstances of genocide and safety risks could impact moral emotions despite contrasting moral standards and judgments. Further research is needed to explore genocide and its additional consequences in terms of moral injury.

Consistent with previous literature, offspring of Holodomor survivors showed specific behavioural strategies related to food, namely, proper feeding, and substantial food storage. (Gorbunova \& Klymchuk, 2020). Surprisingly, food storage and preoccupation with food was also found in offspring of Holocaust survivors. Our data reveal that the strict rituals related to food storage among Israeli families could be a tribute to victims of the Holocaust, while overeating and food storage in Ukrainian families is driven by fear of possible reoccurrence of genocide. Recent findings suggest that there is a possible association between restricted nutrition in early gestation during the Holodomor 1932-1933 and type 2 diabetes in offspring in later life. It can thus be suggested that behavioural strategies of overeating have a poor impact on offspring's health. In addition, there is little research on the association between Holocaust trauma and eating disorders in the Jewish population, notably in offspring of Holocaust survivors (Gorden, 2011). Therefore, this could be an important issue for future research.

Our data yielded many painful memories in Holodomor descendants about dead bodies that were not always buried in individual graves. Mothers and daughters in the Israeli samples mostly spoke about the loss of their childhood and its negative impact on attachments and on mother-daughter relations. In addition, insecure attachment weakens in the younger generations. Comparison of the findings with those of other studies of attachment and trauma, confirms that poor impact of insecure attachment and general adaptation weakens across generations (SagiSchwartz et al., 2003).

A natural progression of this article would be to analyze how death, loss, separation and attachment in family narratives affect mother-daughter relations and their well-being. In addition, our results are consistent with other studies suggesting that after producing traumatic family narratives, individuals may report positive and negative changes in their health (Mohatt, Thompson, Thai, \& Tebes, 2014). Further research is needed to explore the cross-genocide evidence on the impact of the trauma on mothers' and daughters' family narratives, and on how the historical trauma has influenced offspring health and well-being as well as examining the predictors for both positive and negative consequences of the transgenerational narration of the family stories. 
The relevance of ethnic identity is clearly supported by the current findings. Whereas Ukrainian participants tended to eliminate the importance of Ukrainian ethnicity and culture, the Israeli women focused on the symbolic meaning of Zionism for the Jewish people. The core finding of this study points to the centrality of the sense of identity in the family narratives between mothers and daughters. There is prime importance in the sense of who they are and where they come from, and this can provide empathy and understanding in their family history. Additionally, the importance of respect and the need to voice their family narrative may contribute to preventing history repeating itself.

This study has also identified specific themes in the Ukrainian and Israeli samples. In particular, the Ukrainian women reported the importance of remembering and commemorating Holodomor victims as a way of coping with family trauma. In their opinion, commemoration expresses gratitude and positive feeling towards their places of safety. This is in line with previous studies, pointing out that remembering the victims of genocide provides space for great respect for the survival of the older generation and strengthens faith and friendship in Holodomor survivor offspring (Bifulco et al., 2020). Several questions relating to the coping strategy of avoidance still remain to be answered, in particular, freer narrating styles in daughters' interviews in comparison with their mothers. A reasonable approach to tackle this issue could be, on the one hand, to consider the possibility of mothers' re-traumatization and the negative impact on their wellbeing, and, on the other hand, the importance of transgenerational transmission of family narratives for developing family identity and resilience.

The results of this study show that Israeli mothers have adopted the asceticism inherited from Holocaust survivors. Recent research connects Jewish women's asceticism with eating and body disorders derived from the ultra-orthodox Jewish religious environment (Gordon, 2011). However, our research has also shown that ascetic traditions are not transmitted in mother-daughter relations. This may be explained by the fact that asceticism is rather more related to Holocaust survivors limited access to food and then modeling preoccupation with food by the second generation than to a religious environment.

\section{Conclusion}

Our research indicates the intergenerational transmission of trauma and genocide narratives in mother-daughter relationships. Thematic analysis revealed the centrality of themes of "emotions and feelings, experienced during the Holodomor and Holocaust", "attitudes toward food and starvation", "sense of loss and death", "transgenerational transmission of trauma in family narratives", and "ethnic identity" in the traumatic narratives among the second and third generations of survivors of the Holodomor and the Holocaust. Further, the emerging evidence from this study show that the intergenerational transmission of genocide trauma involves multiple and intense emotions, including pain and suffering, anger, fear and disgust. The long-term consequences of these intense emotions are evident in 
the various patterns of insecure attachment manifested by the second and third generations of survivors of the Holodomor and the Holocaust.

The findings of this research shed light on the similarities and differences between the traumatic narratives constructed by the offspring of the second and the third generations. The daughters express more preparedness for sharing traumatic experience, their narratives are longer and more detailed; and their relations with their own children were affected by more secure attachment styles. As a response to the collective trauma, mothers tended to distance themselves from intimacy with their daughters and avoided the detailing of the traumatic narratives.

These findings can contribute in several ways to our understanding of women's transgenerational family narratives and may provide support for the therapeutic use of family stories for strengthening the sense of family identity and enhance resilience. In particular, the women of the third generation are those who could benefit from strengthening the sense of identity and wellbeing among genocide survivors' offspring. The women of the third generation also show higher preparedness for creating comprehensive family narratives and have higher motivation to pass them on to the younger generations.

The study also shed light on the consequences of intergenerational transmission of psychotrauma on both aspects of distress and wellbeing of the subsequent generation and pointed to several relevant risk and protective factors. More specifically, the study focused on the impact of transgenerational family narratives on offspring's intensity of emotions and feelings, on their lifestyle, attitudes toward food, type of attachment, and sense of identity in mother-daughter relations. Thus, the findings of this research bear important implications for future practice that will implement the narrative co-creation of family narratives with survivors of massive trauma and their offspring. The benefits of this co-creation for the healing process from traumatic experiences require further study and evidenced based research. Lately, the focus on ways traumatic family narratives are integrated in motherdaughter relations can expand our theoretical formulations of the intergenerational patterns of transmission of trauma and can provide insights to understanding the mechanisms by which these messages are passed on and internalized.

\section{Acknowledgements}

We express sincere acknowledgements to Holodomor Research and Education Consortium, Canadian Institute of Ukrainian Studies, University of Alberta for financial support of the project "Mental Trauma and Moral Injury in Offspring in Holocaust and Holodomor Survivors".

This paper was supported by the Resilience Research Group at The Hebrew University, Paul Baerwald School of Social Work and Social Welfare. 


\section{References}

Barak, Y., \& Szor, H. (2000). Lifelong posttraumatic stress disorder: evidence from aging Holocaust survivors. Dialogues in Clinical Neuroscience, 2(1), 57-62. https://doi.org/10.31887/DCNS.2000.2.1/ybarak

Bar-On, D., Eland, J., Kleber, R. J., Krell, R., Moore, Y., Sagi, A., ... \& van IJzendoorn, M. H. (1998). Multigenerational perspectives on coping with the Holocaust experience: An attachment perspective for understanding the developmental sequelae of trauma across generations. International Journal of Behavioral Development, 22(2), 315-338. https://psycnet.apa.org/doi/10.1080/016502598384397

Bemporad, E., \& Warren, J. W. (Eds.). (2018). Women and genocide: Survivors, victims, perpetrators. Indiana University Press. https://doi.org/10.2307/j.ctvgd2jm.

Bertelsen, O. (2018). "Hyphenated" Identities during the Holodomor: Women and Cannibalism. https://doi.org/10.2307/j.ctvgd2jm.9

Bianco, L. (2013). From the Great Chinese Famine to the Communist Famines. On Eating Bitterness and the French translation of Mubei. China Perspectives, 2013(2013/3), 85-90. https://doi.org/10.4000/chinaperspectives.6289

Bifulco, A., Spence, R., \& Kagan, L. (2020). Life Events and Emotional Disorder Revisited: Research and Clinical Applications. Routledge. https://doi.org/10.4324/9780429352904.

Bloomington, Indiana, US: Indiana University Press. Retrieved from http://www.jstor.org/stable/j.ctvgd2jm.9

Braga, L. L., Mello, M. F., \& Fiks, J. P. (2012). Transgenerational transmission of trauma and resilience: a qualitative study with Brazilian offspring of Holocaust survivors. BMC Psychiatry, 12(1), 1-11. https://doi:10.1186/1471-244X-12-134

Braun, V., \& Clarke, V. (2006). Using thematic analysis in psychology. Qualitative Research in Psychology, 3(2), 77-101. https://doi.org/10.1191/1478088706qp063oa

Brom, D., Kfir, R., \& Dasberg, H. (2001). A controlled double-blind study on children of Holocaust survivors. The Israel Journal of Psychiatry and Related Sciences, 38(1), 47.

Chalmers, B. (2015). Jewish women's sexual behaviour and sexualized abuse during the Nazi era. The Canadian Journal of Human Sexuality, 24(2), 184-196. http://dx.doi.org/10.3138/cjhs.242-A10

Gorbunova, V.\& Klymchuk, V. (2020). The Psychological Consequences of the Holodomor in Ukraine. East/West: Journal of Ukrainian Studies, 7(2), 33-68. https://doi.org/10.21226/ewjus609

Gorden, C. (2011). Time is on my side: The intergenerational transmission of unmourned trauma and its impact on agency, narrative, and time. Contemporary Psychoanalysis, 47(3), 364-385. https://doi.org/10.1080/00107530.2011.10746464

Elias, B., Mignone, J., Hall, M., Hong, S. P., Hart, L., \& Sareen, J. (2012). Trauma and suicide behaviour histories among a Canadian indigenous population: an empirical exploration of the potential role of Canada's residential school system. Social Science \& Medicine, 74(10), 15601569. https://doi.org/10.1016/j.socscimed.2012.01.026

Fierke, K. M. (2004). Whereof we can speak, thereof we must not be silent: trauma, political solipsism and war. Review of international studies, 30(4), 471-491. https://doi.org/10.1017/S0260210504006187

Freedman, J. R. (2015). Whistling in the Dark: Memory and Culture in Wartime London: University Press of Kentucky.

Hammarström, G. (2005). The construct of intergenerational solidarity in a lineage perspective: A discussion on underlying theoretical assumptions. Journal of Aging Studies, 19(1), 33-51. https://doi.org/10.1016/j.jaging.2004.03.009

Jacobs, J. L. (2004). Women, genocide, and memory: The ethics of feminist ethnography in Holocaust research. Gender \& Society, 18(2), 223-238. https://doi.org/10.1177/0891243203261572 
Kahane-Nissenbaum, M. C. (2011). Exploring intergenerational transmission of trauma in third generation Holocaust survivors. Published by University of Pennsylvania Scholarly Commons, June 23, 2011.

Karenian, H., Livaditis, M., Karenian, S., Zafiriadis, K., Bochtsou, V., \& Xenitidis, K. (2011). Collective trauma transmission and traumatic reactions among descendants of Armenian refugees. International Journal of Social Psychiatry, 57(4), 327-337. https://doi.org/10.1177/0020764009354840

Kis, O. (2020). Women's Experience of the Holodomor: Challenges and Ambiguities of Motherhood. Journal of Genocide Research, 1-20. https://doi.org/10.1080/14623528.2020.1834713

Litz, B.T., Stein, N., Delaney, E., Lebowitz, L., Nash, W.P., Silva, C., \& Maguen, S. (2009). Moral injury and moral repair in war veterans: A preliminary model and intervention strategy. Clinical Psychology Review, 29(8), 695-706. https://doi.org/10.1016/j.cpr.2009.07.003

Naimark, N. M. Fires of Hatred: Ethnic Cleansing in Twentieth-Century Europe. Cambridge and London: Harvard University Press, 2001.

Mohatt, N. V., Thompson, A. B., Thai, N. D., \& Tebes, J. K. (2014). Historical trauma as public narrative: A conceptual review of how history impacts present-day health. Social Science \& Medicine, 106, 128-136. https://doi.org/10.1016/j.socscimed.2014.01.043

Parker, A., \& Tritter, J. (2006). Focus group method and methodology: current practice and recent debate. International Journal of Research \& Method in Education, 29(1), 23-37. https://doi.org/10.1080/01406720500537304

Person, K. (2015). Sexual violence during the Holocaust: the case of forced prostitution in the Warsaw ghetto. Shofar, 33(2), 103-121. https://doi.org/10.5703/shofar.33.2.103

Rajiva, M., \& Takševa, T. (2020). Thinking against trauma binaries: the interdependence of personal and collective trauma in the narratives of Bosnian women rape survivors. Feminist Theory, 1464700120978863. https://doi.org/10.1177/1464700120978863

Richman, S. (2006). Finding one's voice: Transforming trauma into autobiographical narrative. Contemporary Psychoanalysis, 42(4), 639-650. https://doi.org/10.1080/00107530.2006.10747136

Sagi-Schwartz, A., Van IJzendoorn, M. H., Grossmann, K. E., Joels, T., Grossmann, K., Scharf, M., ... \& Alkalay, S. (2003). Attachment and traumatic stress in female Holocaust child survivors and their daughters. American Journal of Psychiatry, 160(6), 1086-1092. https://doi.org/10.1176/appi.ajp.160.6.1086

Shik, N. A. (2009). Sexual abuse of Jewish women in Auschwitz-Birkenau. In Brutality and Desire (pp. 221-246). Palgrave Macmillan, London. http://dx.doi.org/10.1057/9780230234291_9.

Sinnreich, H. J. (2017). Hunger in the ghettos. In The Ghetto in Global History (pp. 110-126). Routledge.

Unger, M. (1998). The status and plight of women in the Lodz Ghetto. In D. Ofer \& L. J. Weitzman, (Eds.). Women in the Holocaust, (pp. 123-142). New Haven: Yale University Press.

Van der Kolk, B. (2015). The Body Keeps the Score: Mind, Brain and Body in the Transformation of Trauma. London: Penguin. https://doi.org/10.1111/1468-5922.12213_1

Waxman, Z. (2017). Women in the Holocaust: a feminist history. Oxford: Oxford University Press.

Weigelin-Schwiedrzik, S. (2006). In search of a master narrative for 20th-century Chinese history. The China Quarterly, 188, 1070-1091. https://doi.org/10.1017/S0305741006000555

Zasiekina, L., \& Zasiekin, S. (2020). Verbal emotional disclosure of moral injury in Holodomor survivors. Psycholinguistics, 28(1), 41-58. https://doi.org/10.31470/2309-1797-2020-28-1-4158 


\section{Appendix}

Table 1

The Level of Interrater Reliability Between Two Analysts in Codes in Ukrainian focus-groups

\begin{tabular}{lll}
\hline Codes in the Ukrainian interviews & Kappa & Quality of agreement \\
\hline Body sensations & .45 & Moderate \\
Emotions & .65 & Substantial \\
Biography & .74 & Substantial \\
Relationship with God & 1.00 & Perfect \\
Crimes & .61 & Substantial \\
Family narratives & .45 & Moderate \\
Evaluation of situation & .78 & Substantial \\
Decision making in insecurity & .50 & Moderate \\
Food & .51 & Moderate \\
Attitude towards self & .78 & Substantial \\
Death & .86 & Substantial \\
Losses & .41 & Moderate \\
Ethnic identity & .66 & Substantial \\
Attitude towards government & .54 & Moderate \\
Time & .63 & Substantial \\
Space & .81 & Substantial \\
Quality of life & .54 & Moderate \\
Awareness & .86 & Perfect \\
Avoidance & .64 & Substantial \\
Family traditions & .63 & Substantial
\end{tabular}

Table 2

The Level of Interrater Reliability Between Two Analysts in Codes in Israeli focus-groups

\begin{tabular}{llc}
\hline Codes in the Israeli interviews & Kappa & Quality of agreement \\
\hline Traumatic characteristics & .87 & Almost perfect \\
Hunger & .87 & Almost perfect \\
Positive life messages & .86 & Almost perfect \\
Negative life messages (don't love, don't & .74 & Substantial \\
believe) & & \\
Childhood loss & .89 & Almost perfect \\
Emotional reactions & .81 & Almost perfect \\
$\begin{array}{l}\text { Excessive responsibility } \\
\text { Refrain from love and attachments }\end{array}$ & .82 & Almost perfect \\
Zionist patriotism & .87 & Almost perfect \\
$\begin{array}{l}\text { Economic life conception (modesty, } \\
\text { asceticism) }\end{array}$ & .95 & Substantial \\
Paternal guideless and direction when & .91 & Perfect \\
choosing a profession & & Perfect \\
Hiding the Holocaust experiences from the & .64 & Substantial \\
second generation and transferring them & & \\
onto the third generation & & \\
\hline
\end{tabular}

